\title{
Optimalisasasi Pembelajaran Agama Hindu Berbasis Aplikasi Online Bagi Siswa Hindu di SMAN 1 Basarang Kabupaten Kapuas
}

\author{
I Gede Dharman Gunawan', Ni Wayan Gateri² \\ ${ }^{12}$ Institut Agama Hindu Negeri Tampung Peyang Palangka Raya \\ ${ }^{1}$ dharman.gunawan@gmail.com, ${ }^{2}$ wayan_gateri@yahoo.co.id
}

\begin{abstract}
The existence of distance learning also demands creativity and innovation of Hindu religious education teachers in managing Hindu religious education learning through online learning applications. The online learning system that is commonly implemented is the teacher using the Whats App (WA) application because it is considered easy and commonly used by students. The teacher creates a class group and then sends materials and assignments through the group. However, it turns out that this is not optimal for the implementation of Hindu religious learning, so it is necessary to optimize Hindu religious education learning by utilizing online learning applications for Hindu students at SMAN 1 Basarang, Kapuas Regency. The purpose of this study was to find out how the process of learning Hindu religion based on online applications at SMAN 1 Basarang, Kapuas Regency. The results of this study include the online application-based Hindu religious learning process at SMAN 1 Basarang, Kapuas Regency, the preparation, implementation, and evaluation of online application-based Hindu learning at SMAN 1 Basarang and efforts to optimize online application-based Hinduism learning at SMAN 1 Basarang from the headmaster's efforts. schools, efforts of Hindu religious education teachers, efforts of educational staff, and student efforts.
\end{abstract}

Keywords: Optimization; Hindu Religion Learning; Online Application

\begin{abstract}
Abstrak
Adanya pembelajaran jarak jauh menuntuk juga kreativitas dan inovasi guru pendidikan agama Hindu dalam mengelola pembelajaran pendidikan agama Hindu melalui aplikasi belajar online. Sistem pembelajaran daring yang umum dilaksanakan yaitu guru yaitu menggunakan aplikasi Whats App (WA) karena dianggap mudah dan biasa dipakai oleh siswa. Guru membuat grup kelas kemudian mengirim materi dan tugas melalui group tersebut. Namun ternyata hal tersebut dirasakan belum optimal untuk pelaksanaan pembelajaran agama Hindu, sehingga perlu adanya optimalisasi pembelajaran pendidikan agama Hindu dengan memanfaatkan aplikasi belajar online bagi siswa Hindu di SMAN 1 Basarang Kabupaten Kapuas. Tujuan penelitian ini untuk mengetahui bagaimana proses pembelajaran agama Hindu berbasis aplikasi online di SMAN 1 Basarang Kabupaten Kapuas. Hasil penelitian ini meliputi proses pembelajaran agama Hindu berbasis aplikasi online di SMAN 1 Basarang Kabupaten Kapuas adanya persiapan, pelaksanaan, dan evaluasi pembelajaran agama Hindu berbasis aplikasi online di SMAN 1 Basarang dan upaya optimalisasi pembelajaran agama Hindu berbasis aplikasi online di SMAN 1 Basarang dari upaya kepala sekolah, upaya guru pendidikan agama Hindu, upaya tenaga kependidikan, dan upaya siswa.
\end{abstract}

Kata Kunci: Optimalisasi; Pembelajaran Agama Hindu; Aplikasi Online 


\section{Pendahuluan}

Pandemi Covid-19 yang terjadi di seluruh belahan negara saat ini, termasuk di Indonesia telah merubah tatanan dalam berbagai bidang, termasuk pada bidang pendidikan. Semua pembelajaran mulai dari pendidikan di taman kanak-kanak sampai pada perguruan tinggi semua memperoleh dampak dari adanya pandemi saat ini. Dalam proses pendidikan misalnya, yang biasanya proses pembelajaran berjalan dengan tatap muka, maka saat ini harus merubah sistem pembelajarannya dengan pembelajaran jarak jauh (PJJ) yang dilakukan dirumah masing-masing secara online dengan menggukan teknologi internet, yang tentunya masih banyak kelemahan-kelemahan atau tantangan dalam proses pelaksanaanya. Tantangan dan masalah-masalah yang muncul dalam proses pelaksanaan daring adalah sangat komplek, mulai dari pendidik, peserta didik, lembaga pendidikan, dan juga orang tua murid. Tantangan pembelajaran daring bagi seorang pendidik adalah kurang atau belum menguasai teknologi secara baik, mencari dan menyiapkan berbagai cara atau materi yang akan diberikan agar tidak monoton tetapi bisa menciptakan pembelajaran yang inovatif sehingga bisa dipahami oleh peserta didik. Sedangkan bagi peserta didik permasalahan yang muncul pada setiap anak adalah kuota internet yang dengan adanya daring ini tentu mengahabiskan banyak kuota (Purnama, 2020).

Dalam pelaksanaan pembelajaran daring memberikan tantangan tersendiri bagi pelaku pendidikan, seperti pendidik, peserta didik, institusi dan bahkan memberikan tantangan bagi masyarakat luas seperti para orang tua. Dalam pelaksanaannya pendidik harus mencari cara bagaimana agar tetap bisa menyampaikan materi pembelajaran dan dapat diterima dengan mudah oleh peserta didik. Begitu juga peserta didik yang dituntut agar bisa menyesuaikan diri dalam situasi dan kondisi seperti saat ini, salah satunya kesiapan mental. Dalam pelaksanaannya pembelajaran daring tentunya tidak dapat terlepas dari peran teknologi. Teknologi dapat mempermudah segala kebutuhan dalam proses belajar mengajar. Sejalan dengan pendapat (Salsabila, 2020) yang mengatakan bahwa tenologi digital dalam lembaga pendidikan sebagai sarana pendukung dalam pembelajaran, baik sebagai sarana dalam mengakses informasi sumber belajar ataupun sebagai sarana penunjang kegiatan belajar dan berkaitan dengan tugas. Seiring dengan perkembangan zaman teknologi semakin berkembang, saat ini banyak platform yang dapat membantu pelaksanaan pembelajaran daring seprti e-learing, Google Clasroom, Edmodo, Moodle, Rumah belajar, dan bahkan platform dalam bentuk video conference sudah semakin banyak diantaranya seperti Google meet, Zoom, dan Visco Webex.

Surat Edaran Menteri Pendidikan menyebutkan bahwa sekolah masih dilarang memasukkan siswa dan seluruh pembelajaran diganti dengan sistem daring (dalam jaringan). Hal ini menuntut kreativitas dan inovasi guru pendidikan agama Hindu dalam mengelola pembelajaran pendidikan agama Hindu melalui aplikasi belajar online. Sistem pembelajaran daring yang umum dilaksanakan yaitu guru yaitu menggunakan aplikasi Whats App (WA) karena dianggap mudah dan biasa dipakai oleh siswa. Guru membuat grup kelas kemudian mengirim materi dan tugas melalui group tersebut (Sarie, 2020). Namun ternyata hal tersebut dirasakan belum optimal untuk pelaksanaan pembelajaran agama Hindu, sehingga perlu adanya optimalisasi pembelajaran pendidikan agama Hindu dengan memanfaatkan aplikasi belajar online bagi siswa Hindu di SMAN 1 Basarang Kabupaten Kapuas.

Oleh sebab itu, peneliti ingin melakukan penelitian yang mengangkat permasalahan tentang bagaimana optimalisasi pembelajaran agama Hindu berbasis aplikasi online bagi siswa Hindu SMAN 1 Basarang Kabupaten Kapuas. 


\section{Metode}

Jenis penelitian yang digunakan dalam penelitian ini adalah penelitian kualitatif. Penelitian kualitatif bertujuan untuk mengembangkan pandangan secara mendetail tentang makna suatu fenomena atau konsep. Fenomena yang dimaksudkan dalam penelitian ini adalah fenomena yang ada di lapangan, baik yang bersifat ilmiah terhadap proses pembelajaran agama Hindu, bagaimana pemanfaatan aplikasi online dalam pembelajaran agama Hindu, dan implikasi terhadap siswa yang berkaitan dengan optimalisasi pembelajaran agama Hindu berbasis aplikasi online bagi siswa Hindu di SMAN 1 Basarang Kabupaten Kapuas saat ini. Lokasi penelitian di SMAN 1 Basarang Kabupaten Kapuas. Berdasarkan pengamatan pendahuluan yang dilakukan peneliti, bahwa guru pendidikan agama Hindu sebelum adanya pandemi covid-19 dalam pembelajaran pendidikan agama Hindu menggunakan metode pembelajaran konvensional (ceramah) diselingi dengan diskusi dengan tatap muka. Namun pada saat pandemi covid-19 yang melanda, mengharuskan guru dan siswa untuk belajar dari rumah. Proses pembelajaran selama pandemi covid-19 ini terus dioptimalkan. Sehingga peneliti mengkaji bagaimana proses pembelajaran agama Hindu dan upaya optimalisasi pembelajaran agama Hindu berbasis aplikasi online di SMAN 1 Basarang Kabupaten Kapuas. Penelitian ini dalam teknik pengumpulan data menggunakan observasi, wawancara, dan dokumentasi.

\section{Hasil dan Pembahasan}

(Susanto, 2020) dalam tulisan pada jurnal ilmiah yang berjudul "Optimalisasi Pembelajaran Pendidikan Agama Islam (PAI) Melalui Google Classroom”. Perkembangan di bidang teknologi informasi dan komunikasi merupakan nikmat dan karunia Allah yang dikaruniakan kepada umat manusia. Fasilitas internet dan media virtual, memudahkan manusia dalam mengakses informasi dan bersosialisasi tanpa disekat oleh ruang dan waktu. Perkembangan ini berdampak positif bagi perkembangan pembelajaran di era digital ini. Pembiasaaan dan optimalisasi pembelajaran pendidikan agama Islam melalui Google Classroom merupakan salah satu cara untuk menumbuh kembangkan kemampuan peserta didik abad ini. Penelitian ini melibatkan siswa-siswi kelas VI di MI Islamyyah Kota Malang. Hasil penelitian ini menunjukkan bahwa optimalisasi pembelajaran melalui Google Classroom memiliki dampak dalam mempersiapkan proses pembelajaran pendidikan agama Islam, sehingga bisa menjadi bekal yang positif dalam memperoleh ilmu pengetahuan (transfer of knowledge).

Berdasarkan kajian tersebut di atas, bahwa optimalisasi pembelajaran melalui Google Classroom memiliki dampak dalam mempersiapkan proses pembelajaran pendidikan agama Islam, sehingga bisa menjadi bekal yang positif dalam memperoleh ilmu pengetahuan. Aplikasi ini bisa dimanfaatkan untuk berdiskusi, saling melempar pertanyaan serta berbagi tugas-tugas yang harus dikerjakan baik mandiri maupun kelompok. Terdapat persamaan dalam penelitian ini yakni sama-sama mengkaji optimalisasi dari pelaksanaan pembelajaran pendidikan agama melalui media aplikasi belajar online. Optimalisasi dari pelaksanaan pembelajaran pendidikan agama Hindu melalui media aplikasi belajar online di SMAN 1 Basarang.

(Nurmila, N., Maslani, M., Tarsono, T., \& Satriah, 2020) dalam penelitiannya yang berjudul "Optimalisasi Pembelajaran Daring di UIN SGD Bandung dalam Upaya Menghentikan Penyebaran Virus Corona". Hasil penelitian ini menunjukkan bahwa pelaksanaan perkuliahan daring di UIN SGD Bandung berjalan dengan menggunakan berbagai media yaitu google classroom, zoom meeting dan elearning UIN SGD Bandung. Pembelajaran berlangsung melalui tahap persiapan, pelaksanaan perkuliahan, evaluasi perkuliahan, dengan memperhatikan respon mahasiswa selama mengikuti perkuliahan. Adapun berbagai kendala yang dihadapi antara lain SDM yang masih gaptek, keterbatasan 
kemampuan menyediakan kuota, sinyal yang kurang, dan gangguan teknis lain pada media daring. Meskipun demikian, pelaksanaan pembelajaran berjalan sukses. Ini terbukti dengan tersampaikan nya materi perkuliahan sesuai rencana pembelajaran, semua mahasiswa dapat mengikuti pembelajaran dengan baik, dan tetap mendapatkan pencerahan tambahan ilmu pengetahuan tanpa harus keluar rumah, sehingga dapat meminimalisir penyebaran Covid-19 di lingkungan UIN Sunan Gunung Djati Bandung. Meskipun dengan berbagai kendala yang dihadapi, pembelajaran daring di Pascasarjana UIN SGD Bandung dapat berjalan secara optimal, sejak persiapan dan prosesnya berkat kerjasama semua pihak, baik dosen, mahasiswa maupun tenaga kependidikan. Keoptimalan proses pembelajaran ini dapat dicapai karena adanya evaluasi yang dilakukan dosen yang ditindak lanjuti dengan upaya perbaikan pada pertemuan selanjutnya.

(Salsabila, 2020) dalam tulisannya berjudul "Peran Teknologi Dalam Pembelajaran Di Masa Pandemi Covid-19". Dalam penelitian ini mengkaji bagaimana peran teknologi dalam pelaksanaan pembelajaran selama masa pandemi Covid-19, selain itu juga mengkaji mengenai tantangan pendidikan selama masa pandemi Covid-19 dengan menggunakan metode literatur bersifat deskriptif-analitis. Hasil dan kesimpulan dalam penulisan ini menunjukkan bahwa, teknologi memiliki peran yang penting terhadap pelaksanaan pembelajaran terlebih di saat pandemi Covid-19 seperti saat ini. Teknologi berperan sebagai media dalam melakukan interaksi antara pendidik dan peserta didik dalam pelaksanaan pembelajaran daring. Selain itu teknologi juga berperan dalam memfasilitasi pendidik untuk menyampaikan materi pembelajaran sehingga pembelajaran tetap berlangsung meskipun tidak dilakukan secara tatap muka langsung. Dalam pelaksanaan pembelajaran daring tentunya terdapat hambatan yang menjadi tantangan tersendiri bagi para pelaku pendidikan, yang berkaitan dengan budaya akademik, meliputi nilai, sikap, pengetahuan, keterampilan, serta kesiapan sarana dan prasarana terkait teknologi. Penyelenggaraan literasi serta pelatihan berkaitan dengan pemanfaatan teknologi dapat menjadi salah satu solusi dalam menghadapi beberapa tantangan pembelajaran daring selama pandemi Covid-19 saat ini.

Jadi, dari paparan singkat tentang hasil bahasan para peneliti terdahulu tersebut memiliki relevansi dengan penelitian ini, akan tetapi masing-masing memiliki perbedaan dengan penelitian ini seperti yang telah disampaikan pada setiap bahasan hasil penelitian di atas. Beberapa hasil penelitian tersebut menunjukkan adanya relevansi tentang optimalisasi pembelajaran pendidikan agama Hindu berbasis aplikasi online bagi siswa Hindu di SMAN 1 Basarang Kabupaten Kapuas.

\section{Proses Pembelajaran Agama Hindu Berbasis Aplikasi Online Di SMAN 1 Basarang Kabupaten Kapuas \\ a. Persiapan Pembelajaran Agama Hindu Berbasis Aplikasi Online di SMAN 1 Basarang}

Proses pembelajaran yang baik tentunya perlu adanya persiapan pembelajaran yang baik pula. Guru wajib melakukan persiapan atau perencanaan sebelum dilaksanakan proses pembelajaran. Perencanaan berasal dari kata "rencana" yang berarti pengambilan keputusan untuk mencapai tujuan. Menurut Ely sebagaimana dikutip Sanjaya mengatakan bahwa perencanaan itu pada dasarnya suatu proses dan cara berpikir yang dapat membantu menciptakan hasil yang diharapkan (Sanjaya, 2008). Perencanaan pembelajaran merupakan suatu pendekatan yang sistematis yang mencakup analisis kebutuhan pembelajaran, perumusan tujuan pembelajaran, pengembangan strategi pembelajaran, pengembangan bahan ajar, serta pengembangan alat evaluasinya dalam upaya mencapai tujuan pembelajaran yang diharapkan (Nasution, 2007). 
Lebih lanjut menurut Sitompul (Nasution, 2007) bahwa Pembelajaran pada hakikatnya merupakan upaya membelajarkan siswa dan perancangan pembelajaran merupakan penataan upaya tersebut agar muncul perilaku belajar. Dalam kondisi yang tertata: tujuan dan isi pembelajaran jelas, strategi pembelajaran optimal, akan amat berpeluang memudahkan belajar. Di pihak lain, peranan pendidik akan menjadi semakin kompleks, ia bukan hanya sebagai salah satu sumber belajar tapi juga harus menampilkan diri sebagai seorang ahli dalam menata sumbersumber belajar lain serta mengintegrasikannya ke dalam tampilan dirinya. Pendidik harus mampu menampilkan diri sebagai satu komponen yang terintegrasi dari keseluruhan sumber belajar.Ini berarti kurang tepat kalau dikatakan bahwa pembuatan perencanaan pembelajaran dimaksudkan untuk memudahkan mengajar. Perencanaan pembelajaran bukan untuk itu, akan tetapi untuk memudahkan peserta didik belajar. Peserta didik yang selayaknya dijadikan kunci akhir dalam menetapkan mutu suatu perencanaan pembelajaran.

Sejalan dengan hal tersebut di atas, Fuyi Yanti Pimae, Kepala SMAN 1 Basarang bahwa Kebijakan yang dilaksanakan terkait dengan pelaksanaan pembelajaran daring di SMAN 1 Basarang seperti penetapan jadwal pembelajaran daring, pelaksanaan kurikulum darurat covid-19, dan peninjauan Laboraturium Komputer untuk seluruh guru dan tenaga pendidik, serta peninjauan bagi siswa yang terkendala dengan handphone/android (wawancara, 11 Juni 2021).

Dari data hasil wawancara di atas, dapat dipahami bahwa Kepala SMAN 1 Basarang telah menetapkan Kebijakan yang telah dilaksanakan terkait dengan persiapan/perencanaan dan pelaksanaan pembelajaran daring di SMAN 1 Basarang seperti penetapan jadwal pembelajaran daring, pelaksanaan kurikulum darurat covid-19, dan peninjauan laboraturium komputer untuk seluruh guru dan tenaga pendidik. Selain itu juga terdapat kebijakan sebelum dilaksanakannya pembelajaran yakni dengan memberikan bantuan Tab android kepada siswa yang terkendala perangkat IT dalam pembelajaran.

Inti utama dalam persiapan atau perancangan pembelajaran adalah pada pemilihan, penetapan, dan pengembangan variabel metode pembelajaran. Pemilihan metode pembelajaran harus didasarkan pada analisis kondisi dan hasil pembelajaran. Analisis akan menunjukkan bagaimana kondisi pembelajarannya dan apa hasil pembelajaran yang diinginkan. Setelah bagaimana kondisi itu, baru penetapan dan pengembangan metode pembelajaran dilakukan. Dalam menentukan metode pembelajaran ada tiga prinsip yang perlu diperhatikan, yaitu: (1) tidak ada satu metode pembelajaran yang unggul untuk semua tujuan dan semua kondisi, (2) metode pembelajaran yang berbeda memiliki pengaruh yang berbeda dan konsisten pada hasil pembelajaran, dan (3) kondisi pembelajaran yang berbeda memiliki pengaruh yang konsisten pada hasil pembelajaran (Nasution, 2007).

Lebih lanjut menurut Ketut Maryani Anjasmari, guru Pendidikan Agama Hindu (wawancara, 11 Juni 2021) menyatakan bahwa "metode yang digunakan sudah efektif dan terealisasi sehingga siswa aktif. Metode pengiriman tugas melalui classroom, WA, dan mengumpulkan langsung ke sekolah. Menggunakan metode secara asinkronus". Berdasarkan hasil wawancara dengan informan di atas, bahwa dalam persiapan atau perencanaan pembelajaran, guru pendidikan agama Hindu juga menyiapkan metode pembelajaran yang akan dipergunakan. Metode yang dipergunakan secara asinkronus dengan pengiriman tugas melalui classroom, WA, dan juga dapat mengumpulkan tugas secara langsung ke sekolah.

Menurut I Wayan Sutirma, guru Pendidikan Agama Hindu (wawancara, 11 Juni 2021) bahwa "pemanfaatan Media Pembelajaran yang digunakan dalam pelaksanaan Pembelajaran agama Hindu secara daring dengan menggunakan video pembelajaran dan aplikasi youtube". Dari data hasil wawancara informan di atas dapat dimaknai bahwa 
dalam proses pembelajaran diperlukan adanya persiapan atau perencanaan pembelajaran seperti pemanfaatan media pembelajaran berupa video pembelajaran yang bersumber dari aplikasi online (youtube).

Persiapan atau perencanaan pembelajaran merupakan suatu pendekatan yang sistematis yang mencakup analisis kebutuhan pembelajaran, perumusan tujuan pembelajaran, pengembangan strategi pembelajaran, pengembangan bahan ajar, serta pengembangan alat evaluasinya dalam upaya mencapai tujuan pembelajaran yang diharapkan. Upaya membuat perencanaan pembelajaran dimaksudkan agar dapat dicapai perbaikan pembelajaran. Prosedur perencanaan pembelajaran yang dibuat berhubungan erat dengan model perencanaan pembelajaran yang dipilih. Persiapan atau perencanaan pembelajaran ini digunakan dalam pembelajaran agama Hindu berbasis aplikasi online di SMAN 1 Basarang Kabupaten Kapuas.

\section{b. Pelaksanaan Pembelajaran Agama Hindu Berbasis Aplikasi Online di SMAN 1 Basarang}

Pelaksanaan pembelajaran adalah proses yang diatur sedemikian rupa menurut langkah-langkah tertentu agar pelaksanaan mencapai hasil yang diharapkan (Sudjana, 2010). Pelaksanaan pembelajaran merupakan kegiatan proses belajar-mengajar sebagai unsur inti dari aktivitas pembelajaran yang dalam pelaksanaannya disesuaikan dengan rambu-rambu yang telah di susun dalam perencanaan sebelumnya. Pelaksanaan pembelajaran adalah suatu kegiatan yang bernilai edukatif, nilai edukatif mewarnai interaksi yang terjadi antara guru dan peserta didik. Interaksi yang bernilai edukatif dikarenakan pelaksanaan pembelajaran yang dilakukan diarahkan untuk mencapai tujuan tertentu yang telah dirumuskan sebelum pelaksanaan pembelajaran dimulai.

Terkait dengan proses pelaksanaan pembelajaran di atas menurut Fuyi Yanti Pimae, Kepala SMAN 1 Basarang, bahwa proses pelaksanaan menggunakan Google Classroom (Asynchronous) seperti daftar hadir, materi pelajaran, umpan balik. Selain itu siswa menggunakan Google Meet dan Zoom (Synchronous) seperti penyampaian dan penjelasan materi, juga pembinaan karakter siswa selama pembelajaran daring (Wawancara, 11 Juni 2021).

Berdasarkan pendapat Fuyi Yanti Pimae di atas, dapat ditegaskan bahwa pelaksanaan pembelajaran berupa kegiatan proses belajar-mengajar yang pelaksanaannya disesuaikan dengan rambu-rambu yang telah di susun dalam perencanaan pembelajaran. Proses pelaksanaan menggunakan Google Classroom (Asynchronous) seperti daftar hadir, materi pelajaran, umpan balik. Selain itu siswa menggunakan Google Meet dan Zoom (Synchronous) seperti penyampaian dan penjelasan materi, juga pembinaan karakter siswa selama pembelajaran daring. Tentunya pelaksanaaan pembelajaran ini disesuaikan dengan tujuan pembelajaran yang diharapkan.

Selanjutnya menurut Ketut Maryani Anjasmari, guru Pendidikan Agama Hindu (Wawancara, 11 Juni 2021) bahwa "proses pelaksanaan pembelajaran daring berjalan sesuai kurikulum dadurat covid-19. Selain teori (kognitif), siswa juga tetap praktek sembahyang, membaca sloka, mengerjakan tugas dengan mengirimkan video sesuai dengan petunjuk tugas". Berdasarkan pendapat tersebut, diketahui bahwa dalam pelaksanaan pembelajaran agama Hindu dengan praktek sembahyang, membaca sloka, mengerjakan tugas dengan mengirimkan video sesuai dengan petunjuk tugas. Serta dalam pelaksanaannnya telah menyesuikan dengan kurikulum darurat yang berlaku.

Pembelajaran merupakan proses interaksi siswa dengan guru dan sumber belajar pada suatu lingkungan belajar. Pembelajaran merupakan bantuan yang diberikan pendidik agar dapat terjadi proses pemerolehan ilmu dan pengetahuan, penguasaan kemahiran dan tabiat, serta pembentukan sikap dan kepercayaan pada siswa. Dengan kata lain, pembelajaran adalah proses untuk membantu siswa agar dapat belajar dengan baik. Proses 
pembelajaran dialami sepanjang hayat seorang manusia serta dapat berlaku di manapun dan kapanpun.

Lebih lanjut menurut I Wayan Sutirma, guru Pendidikan Agama Hindu bahwa pelaksanaan pembelajaran agama Hindu berbasis aplikasi online di SMAN 1 Basarang dengan menggunakan Google Classroom. Adapun yang dipersiapkan seperti membuat daftar hadir siswa, memberikan materi pelajaran, dan memberikan umpan balik (Wawancara, 11 Juni 2021).

Sebagaimana data dari hasil wawancara yang disampaikan informan tersebut di atas bahwa pelaksanaan pembelajaran agama Hindu berbasis aplikasi online di SMAN 1 Basarang dengan menggunakan Google Classroom. Penggunaan Google Classroom ini dalam pelaksanaan pembelajaran agama Hindu dengan memanfaatkan berbagai fitur dalam aplikasi tersebut.

Sejalan dengan pendapat beberapa informan di atas, menurut Made Purbi menyatakan bahwa saya pelaksanaan pembelajaran daring berbasis aplikasi online yang telah dilaksanakan seperti menetapkan kriteria kelulusan minimal, minimal kehadiran $80 \%$. Membuat konsep pembelajaran daring seperti membuat daftar hadir, topic materi, dan umpan balik. Menyiapkan pembelajaran berbasis blended learning yaitu kolaborasi antara tatap muka dan tatap maya (wawancara, 11 Juni 2021).

Dari hasil hasil wawancara di atas diperoleh keterangan bahwa Guru Pendidikan Agama Hindu telah melaksanakan proses pembelajaran agama Hindu berbasis aplikasi online di SMAN 1 Basarang. Pelaksanaan pembelajaran dengan membuat konsep pembelajaran daring seperti membuat daftar hadir, topic materi, dan umpan balik.

Pembelajaran yang baik harus ada interaksi antara guru dengan siswa. Untuk memperoleh pembelajaran yang baik sehingga terjadi interaksi berupa tanya jawab antara guru maupun siswa membutuhkan suatu alat bantu pembelajaran berupa media pembelajaran yang dapat meningkatkan minat dan motivasi belajar siswa dalam proses pembelajaran dan dapat mempermudah guru dalam menyampaikan materi pembelajaran maupun saat ingin mengilustrasikan cara kerja maupun ilustrasi yang lainnya.

\section{c. Evaluasi Pembelajaran Agama Hindu Berbasis Aplikasi Online di SMAN 1 Basarang}

Pembelajaran dapat diartikan sebagai proses kerja sama Antara guru dan peserta didik dalam memanfaatkan segala potensi dan sumber yang ada baik potensi yang ada di dalam maupun potensi di luar peserta didik. Sebagai suatu proses kerja sama, pembelajaran tidak hanya menitikberatkan pada kegiatan guru atau kegiatan peserta didik saja, akan tetapi guru dan peserta didik bersama-sama berusaha mencapai tujuan pembelajaran yang telah ditentukan. Tujuan dari pembelajaran adalah perubahan perilaku peserta didik baik perubahan dari aspek kognitif, afektif, maupun psikomotorik (Sanjaya, 2008). Ada tiga istilah yang sering digunakan dalam evaluasi, yaitu tes, pengukuran dan penilaian (test, measurement, and assessment). Tes merupakan salah satu cara untuk menaksir besarnya kemampuan seseorang secara tidak langsung, yaitu melalui stimulus atau pertanyaan. Tes merupakan salah satu alat untuk melakukan pengukuran dan bagian tersempit dalam evaluasi.

Terkait dengan evaluasi pembelajaran, menurut Ketut Maryani Anjasmari, guru Pendidikan Agama Hindu menyatakan bahwa "kami mengecek absen siswa, setelah itu kami melakukan evaluasi dan control. Apabila terdapat siswa yang kurang aktif, maka kami mendatangi siswa ke rumahnya untuk menanyakan apa saja kendala yang dihadapi selama pembelajaran online. Sehingga pembelajaran agama Hindu dapat berjalan secara optimal" (Wawancara, 11 Juni 2021). Sesuai dengan pendapat tersebut dapat dikatakan bahwa guru dan siswa bersama-sama berusaha mencapai tujuan pembelajaran yang telah ditentukan. Guru pendidikan agama Hindu secara kontinu melaksanakan evaluasi terhadap 
pembelajaran yang diberikan kepada siswa. Guru juga melakukan evaluasi terhadap siswa yang mengalami kendala selama pelaksanaan pembelajaran daring.

Sejalan dengan pendapat informan di atas, I Wayan Sutirma (Wawancara, 11 Juni 2021) menyatakan bahwa "adapun dalam pelaksanaan evaluasi pembelajaran pendidikan agama Hindu menggunakan beberapa tipe soal seperti soal pilihan ganda, soal esay, dan penugasan". Berdasarkan hasil wawancara di atas dapat dideskripsikan bahwa evaluasi yang dilaksanakan dalam pembelajaran agama Hindu berbasis aplikasi online di SMAN 1 Basarang, yaitu tes dan penilaian. Pelaksanaan evaluasi pembelajaran pendidikan agama Hindu menggunakan beberapa tipe soal seperti soal pilihan ganda, soal esay, dan penugasan terkait dengan materi yang telah diberikan kepada siswa.

\section{Upaya Optimalisasi Pembelajaran Agama Hindu Berbasis Aplikasi Online Di SMAN 1 Basarang Kabupaten Kapuas \\ a. Upaya Kepala Sekolah}

Kepala sekolah yang memiliki kompetensi supervisi yang baik nantinya akan dapat membina guru dan mewujudkan peningkatan profesionalitas guru dalam pembelajaran. Kepala sekolah dapat bekerjasama dengan pengawas sekolah untuk memperdalam pemahaman akan supervisi dan meningkatkan profesionalitas guru. Sehingga, program dan tujuan dari sekolah juga akan dengan mudah dicapai serta peningkatan kualitas pendidikan di era revolusi industri juga akan tercapai. Untuk mengembangkan dan meningkatkan kualitas pendidikan, kepala sekolah dapat melakukan tugas dan peran secara profesional dalam kegiatan berikut memberikan umpan balik tentang kinerja guru; mengidentifikasi kebutuhan untuk pengembangan staf; mengidentifikasi potensi untuk promosi; melakukan pemeriksaan jaminan kualitas serta memastikan motivasi dan moral guru dan memberikan dukungan dan bimbingan profesional kepada para guru. Selain itu, kepala sekolah memastikan bahwa lingkungan profesional mendukung proses belajar mengajar. Tujuan akhir dari kegiatan ini adalah untuk meningkatkan kualitas pengajaran dan pembelajaran. Ini berarti bahwa kepala sekolah perlu memainkan peran sebagai perencana; penyelenggara; pemimpin; pembantu; evaluator, penilai, motivator, komunikator, dan pembuat keputusan (Puspitaningtyas et al., 2020).

Kepala sekolah memegang peranan penting dalam membuat kebijakan terkait manajemen krisis atau darurat. Pada masa pandemi Covid-19, kepala sekolah harus memiliki kemampuan untuk mengambil berbagai kebijakan dalam menjamin terselenggaranya proses pendidikan yang bermutu dan tetap mengutamakan keselamatan siswa. Perbaikan terhadap proses belajar mengajar secara terus menerus sangat diperlukan, sehingga dalam kepemimpinannya seorang kepala sekolah harus profesional dan harus memiliki program pendidikan untuk para peserta didik yang perlu direncanakan, diorganisasikan, dilaksanakan dan dievaluasi. Sehingga sebagai seorang yang memimpin pendidikan di sekolahnya, seorang kepala sekolah mengoganisasikan sekolah dan staf yang bekerja di dalamnya ke dalam situasi yang efektif, efisien, demokratis dan keja sama tim.

Terkait dengan upaya kepala sekolah tersebut di atas, maka upaya yang dilakukan kepala SMAN 1 Basarang menurut pendapat Fuyi Yanti Pimae (wawancara, 11 Juni 2021), menyatakan sebagai berikut.

Saya sebagai Kepala Sekolah sangat mendukung pengoptimalisasi pelaksanaan pembelajaran daring agar siswa tetap belajar walaupun secara daring. Upaya yang dilakukan seperti selalu mensuport para siswa dan para guru untuk dapat melaksanakan pembelajaran daring dengan baik. Sesuai kebijakan sekolah yang telah ditetapkan, pembelajaran daring dilaksanakan secara sinkronus dan asinkronus. Selain itu juga sekolah 
berupaya untuk memberikan bantuan kepada para siswa jika mengalami kendala selama pembelajaran daring berlangsung.

Berdasarkan pernyataan yang disampaikan Fuyi Yanti Pimae di atas bahwa sebagai kepala sekolah sangat mendukung pengoptimalisasi pelaksanaan pembelajaran daring agar siswa tetap belajar walaupun secara daring. Upaya yang dilakukan seperti selalu mensuport para siswa dan para guru untuk dapat melaksanakan pembelajaran daring dengan baik. Sesuai kebijakan sekolah yang telah ditetapkan, pembelajaran daring dilaksanakan secara sinkronus dan asinkronus. Kebijakan yang diambil oeh kepala sekolah sesuai dengan visi, misi, dan tujuan sekolah. Kepala sekolah selalu berupaya untuk meyukseskan pelaksanaan pembelajaran di SMAN 1 Basarang.

Sejalan dengan hal tersebut di atas, kegagalan dan keberhasilan sekolah banyak ditentukan oleh kepala sekolah, karena kepala sekolah merupakan pengendali dan penentu kebijakan dalam pencapaian visi, misi dan tujuan sekolah. Oleh karena itu ada beberapa usaha yang sudah dilakukan kepala sekolah dalam meningkatkan kreativitas guru dalam pembelajaran antara lain: (1) Kepala sekolah melakukan supervisi terhadap guru (2) Pemberian pembinaan dan pengembangan (3) Pemberian penghargaan kepada guru yang kreatif (4) Menciptakan suasana kerja yang menyenangkan (Oktavia, 2014).

\section{b. Upaya Guru Pendidikan Agama Hindu}

Guru memegang peranan penting di dalam kelas. Program kelas tidak akan berarti bilamana tidak diwujudkan menjadi kegiatan. Untuk itu upaya guru sangat penting di dalam memberikan pengajaran, kegiatan pengulangan materi, memberikan motivasi, mengembangkan sikap, dan kebiasaan belajar yang baik. Jadi upaya-upaya guru dalam pembelajaran harus disesuaikan dengan siswa, dikarenakan siswa mempunyai tingkat kesulitan belajar berbeda-beda. Upaya guru pendidikan agama Hindu adalah usaha yang dilakukan guru sebagai pendidik profesional dalam mendidik, membimbing, mengarahkan, serta mengevaluasi peserta didik dengan mengembangkan segala potensi yang ada pada diri siswa, baik dari segi kognitif (kecerdasan), afektif (sikap), dan psikomotorik (keterampilan) dalam pembelajaran pendidikan agama Hindu di SMAN 1 Basarang.

Menurut Fuyi Yanti Pimae, Kepala SMAN 1 Basarang menyatakan bahwa "melaksanakan proses pembelajaran daring sesuai dengan kebijakan sekolah yang telah ditetapkan, kemudian para siswa juga mengirimkan video kegiatan yang berkaitan dengan kegiatan Hindu seperti sembahyang, membaca kitab suci, dll" (wawancara, 11 Juni 2021). Berdasarkan hasil wawancara di atas bahwa selama pembelajaran secara daring menggunakan aplikasi online, guru memanfaatkan media video pembelajaran sesuai kegiatan belajar yang berkaitan dengan kegiatan Hindu seperti sembahyang dan membaca kitab suci.

Menurut Ketut Maryati Anjasmari, Guru Pendidikan Agama Hindu (wawancara, 11 Juni 2021) menyatakan bahwa mengikuti program yang telah ditetapkan oleh sekolah untuk pelaksanaan pembelajaran daring. Bagi siswa yang memang tidak bisa mengupayakan mengikuti pembelajaran daring, sekolah berupaya memberikan modul, tugas, dan sebagainya di sekolah. Namun tetap mengikuti protokol kesehatan.

Sesuai dengan data hasil wawancara di atas dapat dimaknai bahwa guru pendidikan agama Hindu telah berupaya mengikuti program yang telah ditetapkan oleh sekolah untuk pelaksanaan pembelajaran daring. Dalam pembelajaran pendidikan agama Hindu berbasis aplikasi online secara daring telah dilaksanakan dan diupayakan oleh guru. Namun jika terdapat siswa yang tidak dapat mengikuti pembelajaran secara daring, guru berupaya memberikan modul, tugas, dan sebagainya di sekolah.

Selanjutnya menurut I Wayan Sutirma, guru pendidikan agama Hindu menyatakan bahwa "lebih memberikan pemahaman kepada siswa bahwa situasi seperti saat ini haris 
dilaksanakan dengan pembelajaran secara online, hal ini demi keamanan dan kesehatan bersama" (wawancara, 11 Juni 2021). Dari hasil wawancara di atas dapat dimaknai bahwa guru pendidikan agama Hindu juga memberikan pemahaman kepada siswa terkaitnya pentingnya selalu menjaga kesehatan selama pandemi covid-19. Proses pembelajaran masih dilaksanakan secara daring. Hal ini untuk menjaga keamanan dan kesehatan semua warga sekolah.

Menurut I Komang Tri Sunarkha Arsana, siswa agama Hindu menyatakan bahwa upaya yang dilakukan guru untuk pelajaran agama Hindu, yaitu seperti memberikan materi pembelajaran, kemudian kami ditugaskan merangkum agar siswa dapat memahami materi pembelajaran dengan merangkum materi yang telah diberikan. Pembelajaran pendidikan agama Hindu juga dengan menggunakan aplikasi online seperti Zoom, sehingga siswa yang kurang paham terhadap materi dapat bertanya secara langsung kepada guru dengan menggunakan aplikasi Zoom tersebut (wawancara, 10 Juli 2021).

Berdasarkan dengan data hasil wawancara di atas dapat dibangun kerangka pemikiran bahwa guru pendidikan agama Hindu telah berupaya melaksanakan proses pembelajaran secara daring dengan memanfaatkan aplikasi belajar online. Adapun upaya yang dilakukan guru untuk pelajaran agama Hindu, yaitu seperti memberikan materi pembelajaran, kemudian siswa ditugaskan untuk merangkum agar siswa dapat memahami materi pembelajaran dengan merangkum materi yang telah diberikan. Dalam penguatan materi pelajaran agama Hindu juga dengan menggunakan aplikasi online seperti Zoom, sehingga siswa yang kurang paham terhadap materi dapat bertanya secara langsung kepada guru dengan menggunakan aplikasi Zoom.

Ni Wayan Oktasanea, siswi agama Hindu menyatakan bahwa keaadaan seperti saat ini kami jarang berinteraksi secara langsung dengan guru. Kami hanya berinteraksi dengan guru melalui aplikasi google classroom dan zoom secara virtual. Guru biasanya memberikan materi dan latihan soal melalui google classroom walaupun sulit dipahami, akan tetapi guru menjelaskan kembali melalui zoom terkait materi pelajaran agama Hindu (wawancara, 10 Juli 2021).

Berdasarkan hasil wawancara dengan informan di atas dapat dipahami bahwa guru pendidikan agama Hindu telah berupaya melaksanakan pembelajaran agama Hindu dengan menggunakan aplikasi belajar online. Hal ini terlihat ketika guru mengajar memberikan materi melalui aplikasi google classroom dan zoom secara virtual. Guru memberikan materi dan latihan soal melalui google classroom, guru juga menjelaskan kembali melalui zoom terkait materi pelajaran agama Hindu. Guru pendidikan agama Hindu telah berupaya menyampaikan materi pelajaran agama Hindu secara sinkronus dan asinkronus.

\section{c. Upaya Tenaga Kependidikan}

Menurut Pasal 1 Undang-undang No. 20 tahun 2003 tentang Sistem Pendidikan. Dalam undang-undang tersebut dinyatakan bahwa Tenaga kependidikan adalah anggota masyarakat yang mengabdikan diri dan diangkat untuk menunjang penyelenggaraan pendidikan. Hal ini telah dipertegas dalam Pasal 39 UU No. 20 tahun 2003 tentang Sisdiknas, yang menyatakan bahwa Tenaga kependidikan bertugas melaksanakan administrasi, pengelolaan, pengembangan, pengawasan, dan pelayanan teknis untuk menunjang proses pendidikan pada satuan pendidikan.

Terkait dengan upaya tenaga kependidikan, menurut Made Purbi (wawancara, 11 Juni 2021) bahwa upaya yang dilakukan seperti mengingatkan tentang pentingnya proses belajar walaupun dilaksanakan secara daring. Selain itu juga membuat struktur pembelajaran yang berbeda namun lebih menarik seperti menambahkan video, permainan, dan lain-lain. Proses pembelajaran daring berbasis aplikasi online di SMAN 1 Basarang sudah berjalan optimal karena sebelum dimulainya pembelajaran online sudah diadakan 
pelatihan penggunaan aplikasi untuk guru dan siswa, serta sekolah juga menyediakan bantuan bagi guru dan siswa yang mengalami kendala.

Sesuai dengan data hasil wawancara dengan informan Made Purbi di atas dapat dimaknai bahwa tenaga kependidikan bertugas melaksanakan administrasi, pengelolaan, pengembangan, pengawasan, dan pelayanan teknis untuk menunjang proses pembelajaran daring di SMAN 1 Basarang. Terkait proses pembelajaran pendidikan agama Hindu menggunakan aplikasi online secara daring sudah berjalan optimal karena telah diadakannya pelatihan penggunaan aplikasi belajar online kepada guru dan siswa.

\section{d. Upaya Siswa}

Menurut (Faruqi, 2018) siswa dapat belajar dengan baik, dalam suasana yang wajar tanpa tekanan dan dalam kondisi yang merangsang untuk belajar. Mereka memerlukan bimbingan dan bantuan untuk mamahami bahan pengajaran dalam berbagai kegiatan belajar. Untuk menciptakan suasana yang menumbuhkan gairah belajar, meningkatkan prestasi belajar siswa, dan lebih memungkinkan guru memberikan bimbingan terhadap siswa dalam belajar, diperlukan pengorganisasian atau pengelolaan kelas yang memadai. Siswa adalah salah satu komponen manusiawi yang menempati posisi sentral dalam proses belajar mengajar dimana di dalam proses belajar mengajar, siswa sebagai pihak yang ingin meraih cita-cita, memiliki tujuan dan kemudian ingin mencapainya secara optimal. Siswa akan menjadi faktor penentu, sehingga dapat mempengaruhi segala sesuatu yang diperlukan untuk mencapai tujuan belajarnya.

Menurut pendapat I Komang Tri Sunarkha Arsana, Siswa Agama Hindu (wawancara, 10 Juli 2021) menyatakan bahwa "belajar dengan sungguh-sungguh dengan mempelajari materi dengan tekun, serta selalu mengerjakan tugas dengan tepat waktu. Sehingga materi pelajaran dan tugas yang diberikan oleh guru dapat dikuasai dengan baik". Lebih lanjut menurut Ni Wayan Oktasanea menyatakan bahwa "pertama berdoa dan sembahyang agar dimudahkan saat belajar, kemudian belajar dengan tekun dan mengerjakan soal-soal yang telah diberikan. Selain itu juga saya secara mandiri membaca dan memahami materi pelajaran" (wawancara, 10 Juli 2021). Berdasarkan hasil wawancara dengan kedua informan di atas, dapat dibangun pemahaman bahwa upaya yang dilakukan siswa dalam mengikuti proses pembelajaran agama Hindu berbasis aplikasi online secara daring dengan tekun dan bersungguh-sungguh dalam belajar serta mengerjakan tugas yang diberikan dengan tepat waktu. Selain itu selalu berdoa dan sembahyang sebelum mengikuti proses pelajaran dari guru.

Menurut I Komang Tri Sunarkha Arsana (wawancara, 10 Juli 2021) menyatakan bahwa "saya proses pembelajaran agama Hindu berbasis aplikasi online sudah berjalan dengan optimal karena pembelajaran sudah terjadwal tiap harinya seperti, adanya pemberian daftar hadir, pemberian materi, pemberian tugas, dan juga pembelajaran secara daring melalui aplikasi Zoom". Sejalan dengan hal tersebut, lebih lanjut menurut Ni Wayan Oktasanea (wawancara, 10 Juli 2021) menyatakan bahwa "saya pembelajaran agama Hindu berbasis aplikasi online sudah optimal karena berjalan dengan sangat baik dan terjadwal. Proses pelaksanaan pembelajaran agama Hindu seperti, pertama pemberian materi melalui google classroom dan selanjutnya guru menjelaskan melalui zoom atau google meet. Sedangkan untuk pemahaman siswa mengerjakan beberapa latihan soal". Berdasarkan hasil wawancara dengan kedua informan di atas, dapat dibangun kerangka pemikiran bahwa siswa mengikuti proses pembelajaran agama Hindu berbasis aplikasi online tiap harinya seperti, adanya pemberian daftar hadir, pemberian materi, dan pemberian tugas dari guru. Siswa juga mengikuti pembelajaran pendidikan agama Hindu dengan baik. 


\section{Kesimpulan}

Berdasarkan uraian yang dikemukakan pembahasan sebelumnya, dapat disimpulkan hasil analisis penelitian ini sebagai berikut. (1) Proses pembelajaran agama Hindu berbasis aplikasi online di SMAN 1 Basarang Kabupaten Kapuas adanya persiapan pembelajaran agama Hindu berbasis aplikasi online di SMAN 1 Basarang, pelaksanaan pembelajaran agama Hindu berbasis aplikasi online di SMAN 1 Basarang, dan evaluasi pembelajaran agama Hindu berbasis aplikasi online di SMAN 1 Basarang. (2) Upaya optimalisasi pembelajaran agama Hindu berbasis aplikasi online di SMAN 1 Basarang dari upaya kepala sekolah, upaya guru pendidikan agama Hindu, upaya tenaga kependidikan, dan upaya siswa.

\section{Daftar Pustaka}

Faruqi, D. (2018). Upaya Meningkatkan Kemampuan Belajar Siswa Melalui Pengelolaan Kelas. Journal EVALUASI, 2(1), 294. https://doi.org/10.32478/evaluasi.v2i1.80

Nasution, W. N. (2007). Perencanaan Pembelajaran: Pengertian, Tujuan Dan Prosedur. Ittihad, $1,186$.

Nurmila, N., Maslani, M., Tarsono, T., \& Satriah, L. (2020). Optimalisasi Pembelajaran Daring di UIN SGD Bandung dalam Upaya Menghentikan Penyebaran Virus Corona. Lembaga Penelitian Dan Pengabdian Kepada Masyarakat., Idi.

Oktavia, Y. (2014). Kreativitas Guru Dalam Pembelajaran Di Sekolah. Jurnal Administrasi Pendidikan, 2(1), 808-815.

Purnama, M. N. A. (2020). Blended Learning Sebagai Sarana Optimalisasi Pembelajaran Daring. SCAFFOLDING: Jurnal Pendidikan Islam Dan Multikulturalisme, 2(2), 106-121.

Puspitaningtyas, I., Imron, A., \& Maisyaroh, M. (2020). Upaya Kepala Sekolah dalam Meningkatan Pembelajaran Guru di Era Revolusi Industri 4.0. Jurnal Manajemen Dan Supervisi Pendidikan, 4(3), 165-172. https://doi.org/10.17977/um025v4i32020p165

Salsabila, U. H. (2020). Peran Teknologi Dalam Pembelajaran Di Masa Pandemi Covid19. Al-Mutharahah: Jurnal Penelitian Dan Kajian Sosial Keagamaan, 17(2), 188198. https://doi.org/10.46781/al-mutharahah.v17i2.138

Sanjaya, W. (2008). Perencanaan dan Desain Sistem Pembelajaran. Jakarta: Kencana.

Sarie, F. N. (2020). Optimalisasi Pembelajaran Daring Masa Pandemi Covid-19 Melalui Aplikasi Edmodo Bagi Siswa Sekolah Dasar. Tunas Nusantara, 2(2), 249-254. https://doi.org/10.34001/jtn.v2i2.1497

Sudjana, N. (2010). Dasar-Dasar Proses Belajar. Bandung: Sinar Baru.

Susanto, E. P. R. (2020). Optimalisasi Pembelajaran Pendidikan Agama Islam (Pai) Melalui Google Classsroom. Jurnal Piwulang, 2(2), 129-143. 